\title{
Ódio, combustível patológico
}

SOLANO, E. G. (org.).

O ódio como política: a reinvenção das direitas no Brasil.

São Paulo: Boitempo, 2018. 128 p.

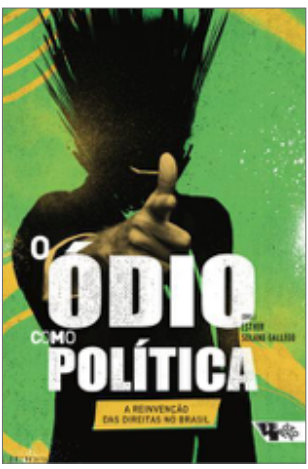

Resumo: O ódio tem surgido sob um discurso plural que vai do neoconservadorismo cultural, passando pelo fundamentalismo religioso e desaguando no ultraliberalismo econômico. Esta obra, reunião de diferentes ensaios, constrói um panorama dos múltiplos caminhos adotados pelas novas direitas políticas em ascensão no Brasil, almejando dar conta da complexa gestão do poder contemporâneo.

Palavras-chave: ódio político; novas direitas; conservadorismo.

Abstract: Hatred, a pathological fuel - Hatred has arisen under a plural speech from cultural neoconservatism, through religious fundamentalism, ending in economic ultraliberalism. This work, encompassing different essays, builds a panorama of the multiple paths adopted by the new right-wing policies on the rise in Brazil, aiming to cope with the complex contemporary power management.

Keywords: political hatred; new right; conservatism.

Uma nova onda conservadora tem surgido e buscado ocupar múltiplos espaços sociopolíticos. Nos últimos anos, diferentes autores têm refletido acerca desse fato, em particular a partir do ódio que parece cimentar transversalmente as tessituras discursivas da complexa gestão do poder nas sociedades contemporâneas.

No mundo, esse ódio tem se configurado sob a forma de diferentes ataques à democracia, conforme demonstrou Jacques Rancière (2014). No Brasil, para Tales 
Ab'Saber (2015), esse sentimento se verteu em uma luta contra um comunismo inexistente, em evocações apaixonadas pelo militarismo e autoritarismo, o que positiva torturas e excludentes de ilicitude como verdadeiras licenças para matar. Se verteu também em cortejos a um fascismo alegre, verde-e-amarelo, com danças e cantos coreografados, e mesmo na promoção de linchamentos simbólicos e reais de adversários políticos, que logo se tornam inimigos a serem extirpados, mortos ou enviados para fora do Brasil, especialmente para Cuba ou Venezuela, como em uma versão 2.0 do Brasil, ame-o ou deixe-o! da ditadura militar, já publicizada em comerciais televisivos.

A obra O ódio como política: a reinvenção das direitas no Brasil organizada pela socióloga e professora de Relações Internacionais da Universidade Federal de São Paulo (Unifesp), Esther Solano, traz uma contribuição ímpar a esse debate, pois a onda conservadora tem sido protagonista não só nos EUA, com a eleição de Donald Trump e a ampliação do poderio do Partido Republicano nas eleições de meio de mandato para o Senado, ou na Zona do Euro, com o Brexit, mas também no Brasil, atingindo seu ápice com a eleição de Jair Bolsonaro para a Presidência. Ao reunir diferentes perspectivas para tentar explicar a reorganização e o fortalecimento da direita brasileira, ou, como fica claro no decorrer dos textos, das novas direitas, os ensaios tentam dar sentido à atual quadra histórica e a algumas expressões, como reacionarismo e neoconservadorismo, explicando o intrincado cenário sociopolítico brasileiro.

O livro se inicia com Luis Felipe Miguel ${ }^{1}$, que apresenta três eixos da extrema-direita brasileira: o libertarianismo, que colocaria o mercado como regulador máximo das relações sociais, o fundamentalismo religioso, que utilizaria o nome de Deus para anular qualquer possibilidade de debate, e a reativação da disputa anticomunista - a reciclagem do perigo vermelho - agora travestida sob o nome de bolivarianismo.

Silvio Almeida busca estabelecer a distinção entre o conservadorismo clássico e o neoconservadorismo contemporâneo. No cenário atual, a democracia seria um detalhe incômodo e, logo, dispensável. Carapanã analisa a normalização do nazismo e do fascismo e as configurações sociopolíticas que geraram uma recessão democrática que ataca os países da América Latina. Assim, segundo ele, para a nova direita:

O Estado que deve ser atacado não é aquele das máquinas de guerra, da repressão policial ou do desrespeito aos cidadãos. O Estado a ser desmontado é aquele que, segundo essa visão, concederia direitos demais - ou mesmo quaisquer direitos às pessoas ou grupos "errados". Se o neoliberalismo desmontou o Estado de bemestar social, a nova direita quer atacar o Estado como ente que garante direitos civis, direitos humanos. (CARAPANÃ, 2018, p.36).

Flávio Henrique Calheiros Casimiro busca as raízes da reorganização das direitas brasileiras a partir do discurso de ódio contra as minorias, movimentos sociais e sindicatos,

1 Neste cenário de ascensão conservadora, convém lembrar o episódio ocorrido com este professor que, ao ministrar uma disciplina optativa na Universidade de Brasília, de nome "O golpe de 2016 e o futuro da democracia no Brasil", foi alvo de investigações e declarações negativas por parte do Ministério da Educação. 
na perseguição a professores, na invasão de universidades, no repúdio ao bem público e na exaltação exacerbada do mercado. Camila Rocha examina a articulação global dos think tanks conservadores e o financiamento de grupos militantes de direita. Rosa PinheiroMachado e Lucia Mury Scalco analisam a substituição da esperança pelo ódio junto à juventude periférica bolsonarista, que deposita fé no armamento da população ao mesmo tempo em que somatiza a desesperança com a quebra do espelho de pertencimento que adivinha do consumo e da ostentação de grifes. Ferréz, cantor de rap, traça um retrato da periferia e do reacionarismo local denunciando o silêncio como arma fatal. Edson Teles reflete sobre a militarização da vida e da política e acerca da dualidade inimigo interno versus cidadão de bem. Como constatou Stephen Graham (2016), há uma transformação da diferença no outro. Em seguida, o outro torna-se alvo e, ato-contínuo, o alvo vira vítima da violência.

Em um dos ensaios de maior destaque por sua pertinência e atualidade, Rubens Casara investiga a direita jurídica e o ativismo judicial sob o viés do forte ideal conservador presente no judiciário nacional. Segundo ele, há um nítido:
aumento da influência de juízes e tribunais nos rumos da vida brasileira, fenômeno correlato à crise de legitimidade de todas as agências estatais. Percebe-se, pois, claramente que o sistema de justiça tornou-se um locus privilegiado da luta política. (CASARA, 2018, p. 75).

Enfocando em questões da seara econômica, Pedro Rossi e Esther Dweck examinam alguns mitos do discurso da austeridade, como a fada da confiança e a metáfora do orçamento familiar, expondo que as políticas de austeridade são seletivas, penalizando ainda mais a parcela mais vulnerável da população nacional, o que resulta em mais desemprego e em mais precariedade, com profundos cortes nas áreas sociais.

Márcio Moretto investiga uma dimensão de vital importância para na atualidade: as redes sociais e como estas organizam o debate político. Este ensaio ilumina um tema incontornável para entender a disputa eleitoral presidencial de 2018, com a explosão das fake news disseminadas especialmente por disparos no WhatsApp. O pastor Henrique Vieira aborda o fundamentalismo e o extremismo que, para ele, não se esgotariam na experiência do sagrado nas religiões. À vista disso, o que ganha luz é o fundamentalismo religioso e como ele se traduz em ações truculentas e projetos de poder, como o desenvolvido pela Frente Parlamentar Evangélica, que visa articular culpa e medo para cercear qualquer ideia ou debate minimamente progressista.

Lucas Bulgarelli analisa os perigos do discurso da moral e dos bons costumes e a sua relação como forte oposição aos direitos LGBTI além da centralidade das disputas em torno de temas morais. Stephanie Ribeiro apresenta as ameaças da retórica antifeminista no ideal de mulher submissa, que ganhou holofotes sob a os cortejos do ponto nodal "bela, recatada e do lar". Denuncia-se, pois, um feminismo pautado na ascensão individual 
e não no rompimento de estruturas opressoras, alertando-se de que o feminismo é uma luta coletiva e não um produto de lifestyle. Por fim, Fernando Penna reflete sobre o caráter reacionário do projeto Escola sem Partido, que fomenta um clima de perseguição inquisitorial em muitas escolas brasileiras sob o lema de um suposto pensamento neutro.

O que se tem nesta obra é uma análise multifacetada com textos fundamentais para entender a ascensão conservadora e a necessidade de investigação do que dela advém, isto é, como compreender a atual complexificação da sociedade brasileira, o ataque ao Estado, sobretudo como garantidor de direitos civis e humanos, a lógica do sistema de produção de subjetividades binárias e antagônicas que operam sob a dinâmica de produção do inimigo interno, a insistência no Brasil violento e de exceção, a erotização do controle pelas tecnologias de segurança e, sobretudo, o investimento libidinoso em violência que insiste em gozos suicidas de ódio.

Filipe Aquino é mestre em Comunicação e Semiótica (PUCSP) e doutor em Sociologia (Universidade do Porto - Portugal).

filipecaquino@gmail.com

\section{Referências}

AB'SABER, T. Dilma Rousseff e o ódio político. Hedra: São Paulo, 2015.

GRAHAM, S. Cidades sitiadas: o novo urbanismo militar. São Paulo: Boitempo, 2016.

RANCIÈRE, J. O ódio à democracia. São Paulo: Boitempo, 2014.

SOLANO, E. G. (org.). O ódio como política: a reinvenção das direitas no Brasil. São Paulo: Boitempo, 2018. 